\title{
Survey Of Management Facilities And Infrastructure Of Physical Education In Special Needs School In Malang City
}

\author{
Laila Nur Rohmah ${ }^{1)}$, Luthfie Lufthansa ${ }^{2)}$, Habibulloh Mustofa ${ }^{3)}$ \\ ${ }^{1,2,3}$ Program Studi Pendidikan Jasmani Kesehatan dan Rekreasi \\ Fakultas Pendidikan Ilmu Eksakta dan Keolahragaan \\ IKIP Budi Utomo Malang, Jawa Timur Indonesia \\ Email: ${ }^{1}$ laila@ budiutomomalang.ac.id, ${ }^{2}$ luthfie@ budiutomomalang.ac.id, \\ habibulloh@budiutomomalang.ac.id
}

\begin{abstract}
This study aims to determine the management process that includes planning, procurement, use, maintenance, control, and condition of physical education facilities and infrastructure in SLB throughout Malang City in 2018. Qualitative descriptive methods with research subjects: school principals, health teachers, and students with special needs. Data collection methods by interview, observation, and documentation. Analyzed through data reduction, data presentation, and drawing conclusions. The results showed that the management of physical education facilities and infrastructure in SLB throughout Malang was quite good with the following results the suitability value is $76 \%$. SDLB Sumber Darma has a process suitability value of 60\%, SDLB BCG Idayu 64\%, SDLB Putra Jaya 60\% and SDLB River Kids 64\%. The average suitability of the implementation process of the management of physical education infrastructure facilities in Malang City Elementary School SDLB is $64 \%$ in the quite good category.
\end{abstract}

Keywords: Management, Facilities and Infrastructure, Physical Education

\section{Survei Pengelolaan Sarana Dan Prasarana Sekolah Luar Biasa Pendidikan Jasmani Se-Kota Malang \\ ABSTRAK}

Tujuan penelitian ini untuk mengetahui proses manajemen yang meliputi kegiatan perencanaan, pengadaan, penggunaan, pemeliharaan, pengendalian, dan kondisi sarana dan prasarana pendidikan jasmani di SLB se-Kota Malang Tahun 2018. Metode deskriptif kualitatif dengan subjek penelitian: kepala sekolah, guru penjaskes, dan siswa berkebutuhan khusus. Metode pengumpulan data dengan wawancara, observasi, dan dokumentasi. Kemudian dianalisis melalui reduksi data, penyajian data, dan penarikan kesimpulan. Hasil penelitian menunjukkan bahwa manajemen sarana dan prasarana pendidikan jasmani di SLB se-Kota Malang cukup baik dengan hasil sebagai berikut nilai prosentase kesesuaian $76 \%$. Kemudian SDLB Sumber Darma memiliki nilai kesesuaian proses $60 \%$, SDLB BCG Idayu 64\%, SDLB Putra Jaya 60\% dan SDLB River Kids $64 \%$. Rata rata kesesuaian proses pelaksanaan pengelolaan sarana prasarana pendidikan jasmani SDLB Kota Malang sebesar 64\% dalam kategori cukup baik.

Kata Kunci: Manajemen, Sarana dan Prasarana, Pendidikan Jasmani

Info Artikel

Dikirim

Diterima

Dipublikasikan
(C) 2020 IKIP BUDI UTOMO MALANG

P-ISSN 2613-9421

E-ISSN 2654-8003 


\section{PENDAHULUAN}

Peran penting pengelolaan sarana dan prasarana sekolah telah banyak dikemukakan dalam banyak penelitian. Sarana prasarana pendidikan mampu mempengaruhi keberhasilan pendidikan (Darmastuti, 2014). Sarana dan prasarana pendidikan merupakan salah satu sumber daya yang penting dan utama dalam menunjang proses pembelajaran di sekolah (Bancin \& Lubis, 2017), serta merupakan bagian yang tidak dapat dipisahkan dari manajemen pendidikan (Megasari, 2014). Lebih dari sekedar untuk kemudahan akan tetapi juga untuk efisiensi dan efektifitas proses pembelajaran (Rahayu, 2019). Bahkan (Kurniawati \& Sayuti, 2013) lebih tegas menyebutkan bahwa keberadaan sarana dan prasarana sangat mutlak dibutuhkan dalam proses pendidikan apalagi jika diimbangi dengan sistem pengelolaan dan pemanfaatan yang memadai. (Satori \& Irawan, 2013) menemukan bahwa ada pengaruh yang signifikan antara efektifitas manajemen sarana dan prasarana sekolah terhadap efektifitas pembelajaran.

Manajemen atau pengelolaan sarana prasarana pendidikan meliputi 4 (empat) prosedur kegiatan yakni (1) perencanaan; meliputi analisa kebutuhan, rancangan pembelian dan pengadaan, rencana rehabilitasi, sampai rancangan proses pengelolaan secara menyeluruh yang terangkum dalam Rencana Kerja Sekolah (RKS), (2) pengadaan; merupakan serangkaian kegiatan untuk menyediakan sarana dan prasarana pendidikan sesuai dengan kebutuhan, baik berkaitan dengan jenis dan spesifikasi, jumlah, waktu maupun tempat, dengan harga dan sumber yang dapat dipertanggungjawabkan, (3) pemeliharaan; meliputi penyimpanan, inventarisasi dan pencatatan penggunaan, serta perbaikan (repaire) (4) penghapusan; proses kegiatan yang bertujuan untuk mengeluarkan/ menghilangkan sarana dan prasarana dari daftar inventaris, kerena sarana dan prasarana tersebut sudah dianggap tidak berfungsi sebagaimana yang diharapkan terutama untuk kepentingan pelaksanaan pembelajaran di sekolah, (5) pelaporan; meliputi laporan triwulan dan tahunan (Kemendikbud, 2019). Ketepatan prosedur dalam melaksanakan kegiatan-kegiatan tersebut diatas dapat dijadikan acuan untuk mengetahui apakah suatu proses pengelolaan sarana prasana berlangsung dengan baik atau tidak. 
Pentingnya ketepatan prosedur pengelolaan sarana prasarana sekolah tersebut diatas sayangnya seringkali tidak disadari oleh pengampu kebijakan dan pelaksana lapangan di sekolah. Selain itu, anggapan umum menyatakan bahwa masih banyak disekolah-sekolah dasar sarana dan prasarana pendidikan tidak dimanejemeni dengan baik disebabkan kebanyakan guru Pendidikan Jasmani atau petugas, tidak dibekali manajemen pengelolaan sarana dan prasarana olahraga yang baik. Maka penelitian yang berjudul "Survei Manajemen Pengelolaan Sarana dan Prasarana Pendidikan Jasmani di Sekolah Luar Biasa se-Kota Malang“. Penelitian ini hanya berfokus pada populasi Sekolah Dasar Luar Biasa (SDLB) Kota Malang. Sarana dan prasarana pun dibatasi hanya pada sarana dan prasarana yang berkaitan dengan pendidikan jasmani. Hal tersebut dilakukan untuk menjaga kesamaan dan keseragaman analisis data kebutuhan sehingga acuan standar berkaitan dengan pengelolaan sarana prasarana dapat diambil. Karena karakteristik, profil, tujuan serta kurikulum antara SDLB berbeda dengan SMPLB dan SMALB. Tujuan dari penelitian ini adalah (1) untuk mengetahui jumlah dan kondisi sarana prasarana Pendidikan Jasmani di SDLB, (2) untuk mengetahui bagaimana proses atau prosedur pengelolaan sarana prasarana Pendidikan Jasmani di Sekolah Dasar Luar Biasa (SDLB), (3) untuk mengetahui kesesuaian/keterlaksanaan proses pengelolaan sarana prasarana Pendidikan Jasmani terhadap tahap proses pengelolaan sarana prasarana sekolah versi Kemendikbud.

\section{METODE}

Penelitian ini menggunakan metode penelitian kualitatif dengan pendekatan deskriptif kualitatif. Dengan mengambil populasi penelitian berjumlah 5 Sekolah Dasar Luar Biasa di Kota Malang, yang mana seluruh populasi tersebut akan sekaligus dijadikan sampel penelitian. Teknik pengumpulan data menggunakan cara observasi, wawancara dan studi dokumentasi. Wawancara dilakukan kepada informan yakni kepala sekolah, guru, petugas administrasi serta perwakilan orang tua wali murid. Wawancara bertujuan untuk menggali seluruh informasi yang berkaitan dengan proses pengelolaan sarana dan prasarana Pendidikan Jasmani di SDLB. Observasi dilakukan dengan instrumen lembar observasi yang berisi 
tentang tahapan proses pengelolaan sarana dan prasarana yang diterjemahkan dalam item-item ceklis indikator yang merujuk pada Modul Pengelolaan Sarana dan Prasarana Sekolah (MPPKS-SAR) yang diterbitkan oleh Kemendikbud pada tahun 2019 seperti pada tabel 1 di bawah. Studi dokumentasi dan arsip digunakan untuk mengumpulkan data yang berkaitan dengan arsip mengenai pembukuan inventarisasi dan pencatatan yang dilakukan selama proses pengelolaan sarana prasarana berlangsung. Keabsahan data diukur dengan triangulasi sumber.

Tabel 1. Ceklis Lembar Observasi Tahapan Proses Pengelolaan Sarana Prasarana Sekolah

\begin{tabular}{|c|c|}
\hline $\begin{array}{l}\text { Tahap Proses } \\
\text { Pengelolaan }\end{array}$ & Kegiatan \\
\hline \multirow[t]{4}{*}{ 1. Perencanaan } & $\begin{array}{l}\text { a. Analisa dan menyusun daftar keperluan sarana } \\
\text { prasarana sesuai dengan RKS. }\end{array}$ \\
\hline & $\begin{array}{l}\text { b. Menyusun rencana pengadaan beserta perkiraan } \\
\text { biaya pemenuhan sarana prasarana. }\end{array}$ \\
\hline & $\begin{array}{l}\text { c. Melakukan penetapan skala prioritas berdasarkan } \\
\text { anggaran dana dan urgensi kebutuhan. }\end{array}$ \\
\hline & $\begin{array}{l}\text { d. Menyusun rencana pengadaan tahunan dan } \\
\text { menyusun Rencana Anggaran Biaya (RAB) }\end{array}$ \\
\hline \multirow[t]{9}{*}{ 2. Pengadaan } & e. Menyusun panitia pengadaan. \\
\hline & $\begin{array}{l}\text { f. Menyusun jadwal pengadaan beserta cara } \\
\text { pelaksanaannya. }\end{array}$ \\
\hline & $\begin{array}{l}\text { g. Menyusun dan menyiapkan Harga Perkiraan } \\
\text { Sendiri (HPS). }\end{array}$ \\
\hline & $\begin{array}{l}\text { h. Mempersiapkan dokumen lelang beserta kebutuhan } \\
\text { administratif lainnya. }\end{array}$ \\
\hline & i. Membuat laporan proses dan hasil lelang. \\
\hline & $\begin{array}{l}\text { j. Menunjuk tenaga ahli jika pengadaan dilakukan } \\
\text { dengan membuat sendiri. }\end{array}$ \\
\hline & $\begin{array}{l}\text { k. Membuat berita acara jika pengadaan dilakukan } \\
\text { dengan hibah. }\end{array}$ \\
\hline & $\begin{array}{l}\text { 1. Membuat surat perjanjian sewa jika pengadaan } \\
\text { dilakukan dengan cara menyewa. }\end{array}$ \\
\hline & $\begin{array}{l}\text { m. Membuat surat perjanjian pinjam jika pengadaan } \\
\text { dilakukan dengan cara meminjam. }\end{array}$ \\
\hline \multirow[t]{5}{*}{ 3. Inventarisasi } & $\begin{array}{l}\text { n. Membuat dan menyusun Buku Induk Barang } \\
\text { Inventaris }\end{array}$ \\
\hline & $\begin{array}{l}\text { o. Membuat dan menyusun Buku Golongan Barang } \\
\text { Inventaris. }\end{array}$ \\
\hline & p. Buku Catatan Barang Non-Inventaris. \\
\hline & $\begin{array}{l}\text { q. Daftar Laporan Triwulan Mutasi } \\
\text { Inventaris. }\end{array}$ \\
\hline & r. Membuat Daftar Isian Inventaris \\
\hline
\end{tabular}




\begin{tabular}{ll}
\hline 4. Penyimpanan & $\begin{array}{l}\text { s. Tersedianya tempat penyimpanan yang aman, } \\
\text { bersih, rapi dan terawat. }\end{array}$ \\
\hline $\begin{array}{l}\text { 5. Pemeliharaan } \\
\text { dan }\end{array}$ & t. $\begin{array}{l}\text { Membuat aturan penggunaan bagi seluruh warga } \\
\text { sekolah. }\end{array}$ \\
\hline & $\begin{array}{l}\text { Perawatan } \\
\text { v. Perawatan rutin dan berkala. }\end{array}$ \\
\hline 6. Penghapusan & $\begin{array}{l}\text { w. Membuat daftar barang yang akan dihapus, untuk } \\
\text { kemudian diusulkan kepada pihak yang } \\
\text { berwenang. }\end{array}$ \\
\hline 7. Pelaporan & x. Menyusun laporan triwulan, \\
\hline & y. Menyusun laporan tahunan. \\
\hline
\end{tabular}

Disarikan dari (Kemendikbud, 2019)

Penelitian menggunakan analisis data model interaktif (Miles \& Huberman, 1992) dengan prosedur: (1) reduksi data; data yang didapat dari wawancara dipilih dan dipilah, disederhanakan untuk mendapatkan fokus domain penelitian, (2) penyajian data; terdapat 2 sajian data yakni data yang berkaitan dengan jumlah dan kondisi alat pendidikan jasmani, serta data yang didapat melalui lembar observasi yang memuat ceklis kesesuaian/keterlaksanaan proses yang terjadi dengan membandingkan indikator proses pengelolaan sarana prasarana sekolah yang diterbitkan Kemendikbud, kemudian disajikan dengan kriteria prosentase kesesuaian seperti pada tabel 1, dan (3) penarikan simpulan; dari data wawancara dan observasi, kemudian diambil kesimpulan.

Tabel 2. Kriteria Keterlaksanaan Proses Pengelolaan Sarana Prasarana Pendidikan Jasmani SDLB

\begin{tabular}{c|c}
\hline Prosentase Keterlaksanaan & Kriteria \\
\hline $80 \% \leq \mathrm{PK} \leq 100 \%$ & Baik \\
\hline $60 \% \leq \mathrm{PK}<80 \%$ & Cukup Baik \\
\hline $40 \% \leq \mathrm{PK}<60 \%$ & Kurang Baik \\
\hline $\mathrm{PK}<40 \%$ & Buruk \\
\hline
\end{tabular}

(Hobri, 2010)

\section{HASIL DAN PEMBAHASAN}

Terdapat 8 Sekolah Dasar Luar Biasa yang terdaftar di Kota Malang. Penelitian ini direncanakan menggunakan model total sampling, akan tetapi hanya 5 SDLB yang mengijinkan tim peneliti untuk melakukan penelitian. 3 SDLB yang tidak mengijinkan memberikan dengan alasan bahwa (1) SDLB sedang melakukan perombakkan susunan pengelola yayasan, (2) SDLB tidak bersedia 
membuka data dan diwawancarai, (3) pihak SDLB merasa berjuang mempertahankan keberlanjutan sekolah yang mereka kelola.

\section{A. Data Sarana dan Prasarana SDLB}

Data-data mengenai sarana dan prasarana Sekolah Dasar Luar Biasa di Kota Malang dalam kegiatan belajar mengajar pendidikan jasmani:

1. SDLB Negeri Kedung Kandang

SDLB Kedung Kandang ialah salah satu SDLB Negeri yang berlokasi di Jalan H. Nasrudin No. 2 Kota Malang, SLB Negeri Kedung Kandang ini sudah terakreditasi A dengan nomor npsn 20533636. Sarana prasarana pendidikan jasmani yang dimiliki SLB Negeri Kedung Kandang yaitu:

Tabel 3 Jumlah dan Kondisi Sarana dan Prasarana Pendidikan Jasmani SLB Negeri Kedung Kandang

\begin{tabular}{clccc}
\hline NO & \multicolumn{1}{c}{ SARPRAS } & JUMLAH & BAIK & RUSAK \\
\hline 1. & Bola Sepak & 3 & 2 & 1 \\
\hline 2. & Bola Voli & 2 & 2 & - \\
\hline 3. & Bola Plastik & 4 & 3 & 1 \\
\hline 4. & Bola Basket & 2 & 2 & - \\
\hline 5. & Bola Kasti & 3 & 3 & - \\
\hline 6. & Bola Pingpong & 2 slop & 2 slop & - \\
\hline 7. & Raket Bulutangkis & 5 & 5 & - \\
\hline 8. & Shuttlecock & 3 slop & 3 slop & - \\
\hline 9. & Bed Tenis Meja & 2 & 2 & - \\
\hline 10. & Skiping & 1 & 1 & - \\
\hline 11. & Tolak Peluru (small) & 3 & 3 & - \\
\hline 12. & Pemukul Kasti & 2 & 2 & - \\
\hline 13. & Net Tenis Meja & 1 & 1 & - \\
\hline 14. & Cakram & 1 & 1 & - \\
\hline \multicolumn{7}{r}{} & JUMLAH & $\mathbf{3 4}$ & $\mathbf{3 2}$ & $\mathbf{2}$ \\
\hline
\end{tabular}

Untuk prasarana lapangan olahraga di SDLB Negeri Kedung Kandang memiliki 1 lapangan/halaman di dalam sekolah, tetapi peserta didik saat kegiatan olahraga, mereka menggunakan lapangan sepak bola Jagung yang berjarak $100 \mathrm{~m}$ dari sekolah.

\section{SLB Sumber Dharma}

SDLB Sumber Dharma merupakan SDLB Swasta yang terletak di Jl. Candi Jago No. 28 Blimbing, Kota Malang. SDLB Sumber Dharma ini sudah terakreditasi B dengan nomor npsn 69861155. Sarana prasarana pendidikan jasmani yang dimiliki SLB Sumber Dharma yaitu: 
Tabel 3. Jumlah dan Kondisi Sarana dan Prasarana Pendidikan Jasmani SDLB Sumber Dharma

\begin{tabular}{clccc}
\hline NO & \multicolumn{1}{c}{ SARPRAS } & JUMLAH & BAIK & RUSAK \\
\hline 1. & Bola Sepak & 2 & 2 & - \\
\hline 2. & Bola Karet & 3 & 3 & - \\
\hline 3. & Bola Plastik & 2 & 2 & - \\
\hline 4. & Bola Basket & 1 & 1 & - \\
\hline 5. & Bola Kasti & 3 & 3 & - \\
\hline 6. & Bola Bocce & 6 & 6 & \\
\hline 7. & Bola Pingpong & 3 slop & 3 slop & - \\
\hline 8. & Raket Bulutangkis & 14 & 12 & 2 \\
\hline 9. & Shuttlecock & 5 slop & 5 slop & - \\
\hline 10. & Bed Tenis Meja & 8 & 8 & - \\
\hline 11. & Skiping & 4 & 4 & - \\
\hline 12. & Tolak Peluru (small) & 2 & 2 & - \\
\hline 13. & Net Bola Voli & 1 & 1 & - \\
\hline 14. & Net Tenis Meja & 2 & 2 & - \\
\hline 15. & Cakram & 1 & 1 & - \\
\hline & JUMLAH & $\mathbf{5 7}$ & $\mathbf{5 5}$ & $\mathbf{2}$ \\
\hline
\end{tabular}

Adapun meja tenis dan matras yang kondisinya masih bagus, tetapi sekolah tidak bisa mengaplikasikan dikarenakan tidak ada guru khusus yang mengampu atau mengurus segala sesuatu berkenaan dengan sarana dan prasarana Penjaskes. Lapangan yang digunakan untuk kegiatan olahraga di SDLB Sumber Dharma yaitu menyewa lapangan di Universitas ABM. Di Universitas ABM tersedia lapangan basket, voli, dan lapangan futsal.

3. SDLB BCG Idayu

SDLB BCG Idayu yaitu sebuah SDLB Swasta yang beralamat di Perum Graha Permata Sulfat Kav. 3 Bunulrejo Blimbing, Kota Malang. SDLB BCG Idayu ini sudah terakreditasi B dengan nomor npsn 69880235. Sarana prasarana pendidikan jasmani yang dimiliki SDLB Sumber Dharma yaitu:

Tabel 3. Jumlah dan Kondisi Sarana dan Prasarana Pendidikan Jasmani SDLB BCG Idayu

\begin{tabular}{clccc}
\hline NO & \multicolumn{1}{c}{ SARPRAS } & JUMLAH & BAIK & RUSAK \\
\hline 1. & Bola Sepak & 3 & - & 3 \\
\hline 2. & Bola Plastik & 3 & 3 & 1 \\
\hline 3. & Bola Basket & 2 & 2 & - \\
\hline 4. & Pelampung & 3 & 3 & - \\
\hline 5. & Kaca Mata Renang & 3 & 3 & - \\
\hline 6. & Raket Bulutangkis & 12 & 8 & 4 \\
\hline 7. & Shuttlecock & 4 slop & 4 slop & - \\
\hline 8. & Bed Tenis Meja & 3 & 3 & - \\
\hline
\end{tabular}




\begin{tabular}{clccc}
\hline 9. & Skiping & 4 & 4 & - \\
\hline 10. & Papan Catur & 2 & 2 & - \\
\hline 11. & Hulahup & 3 & 3 & - \\
\hline & JUMLAH & $\mathbf{4 2}$ & $\mathbf{3 4}$ & $\mathbf{8}$ \\
\hline
\end{tabular}

SDLB BCG Idayu memiliki sarana dan prasarana yang jarang ditemukan di sekolah lain seperti, pelampung, kaca mata renang, papan catur, dan hulahup. SLB BCG Idayu mempunyai kolam renang meskipun kolam renangnya itu menyewa. Kolam renang tersebut berjarak $200 \mathrm{~m}$ dari sekolah. SDLB BCG Idayu memanfaatkan halaman balai desa Perumahan Graha Permata Sulfat.

4. SDLB Putra Jaya

SDLB Putra Jaya merupakan SDLB Swasta merupakan satu dari sekian SDLB Swasta yang terletak di J1. Nusa Indah No. 11/A Lowokwaru, Kota Malang. SDLB Putra Jaya ini sudah terakreditasi B dengan nomor npsn 20533762. Sarana prasarana pendidikan jasmani yang dimiliki SDLB Putra Jaya yaitu:

Tabel 4. Jumlah dan Kondisi Sarana dan Prasarana Pendidikan Jasmani SDLB Putra Jaya

\begin{tabular}{clccc}
\hline NO & \multicolumn{1}{c}{ SARPRAS } & JUMLAH & BAIK & RUSAK \\
\hline 1. & Bola Sepak & 7 & 4 & 3 \\
\hline 2. & Bola Voli & 4 & 2 & 2 \\
\hline 3. & Bola Basket & 3 & 2 & 1 \\
\hline 4. & Bola Kasti & 8 & 8 & - \\
\hline 5. & Bola Pingpong & 2 slop & 2 slop & - \\
\hline 6. & Raket Bulutangkis & 19 & 11 & 8 \\
\hline 7. & Shuttlecock & 7 slop & 4 slop & 3 \\
\hline 8. & Bed Tenis Meja & 1 & 1 & - \\
\hline 9. & Tolak Peluru $($ small $)$ & 2 & 2 & - \\
\hline 10. & Pemukul Kasti & 2 & 2 & - \\
\hline 11. & Cakram & 2 & 2 & - \\
\hline 12. & Sepeda Statis & 1 & 1 & - \\
\hline 13. & Tongkat Estafet & 5 & - & 5 \\
\hline 14. & Net Bola Voli & 2 & 2 & - \\
\hline 15. & Net Bulutangkis & 2 & 2 & - \\
\hline 16. & Bola Bocce & 6 & 6 & - \\
\hline & JUMLAH & $\mathbf{7 3}$ & $\mathbf{5 1}$ & $\mathbf{2 2}$ \\
\hline
\end{tabular}

SDLB Putra Jaya memiliki sarana dan prasarana yang paling banyak diantara SDLB lainnya. SDLB Putra Jaya memiliki halaman dengan luas 10 x $6 \mathrm{~m}$ 
yang digunakan untuk senam dan permainan bola bocce. Untuk lari peserta didik memanfaatkan jalan yang berada di belakang sekolah.

5. SDLB Autisme River Kids

SDLB Autisme River Kids merupakan SDLB Swasta yang terletak di Perum Uniga 41 Joyo Grand Atas, Merjosari, Kota Malang. SDLB Autisme River Kids ini sudah terakreditasi B dengan nomor npsn 20539435. Sarana prasarana pendidikan jasmani yang dimiliki SDLB Autisme River Kids yaitu:

Tabel 6. Jumlah dan Kondisi Sarana dan Prasarana Pendidikan Jasmani SDLB Autisme River Kids

\begin{tabular}{clccc}
\hline NO & \multicolumn{1}{c}{ SARPRAS } & JUMLAH & BAIK & RUSAK \\
\hline 1. & Bola Sepak & 1 & - & 1 \\
\hline 2. & Bola Plastik & 1 & 1 & - \\
\hline 3. & Bola Karet & 3 & 3 & - \\
\hline 5. & Pemukul Kasti & 1 & 1 & - \\
\hline 6. & Raket Bulutangkis & 3 & 3 & - \\
\hline 7. & Shuttlecock & 3 slop & 3 slop & - \\
\hline 9. & Skiping & 1 & 1 & - \\
\hline 10. & Skateboard & 1 & 1 & - \\
\hline 11. & Samsak & 1 & 1 & - \\
\hline 12. & Trampolin & 1 & 1 & - \\
\hline 13. & Net Bulutangkis & 1 & 1 & - \\
\hline \multicolumn{7}{c}{ JUMLAH } & $\mathbf{1 7}$ & $\mathbf{1 6}$ & $\mathbf{1}$ \\
\hline
\end{tabular}

SDLB Autisme River Kids menggunakan/menyewa aula bulutangkis serba guna sebagai lapangan.

\section{B. Pelaksanaan Tahap Proses Pengelolaan Sarana Prasarana SDLB}

Data diperoleh melalui lembar observasi yang berisi indikator proses tahapan pengelolaan yang disarikan dari modul yang diterbitkan Kemendikbud. Kemudian dari data tersebut dapat diketahui prosentase tingkat kesesuaian atau keterlaksanaan proses pengelolaan sarana prasarana yang ada di sekolah terhadap acuan modul pengelolaan sarana prasarana yang diterbitkan Kemendikbud. Seperti grafik di bawah ini: 


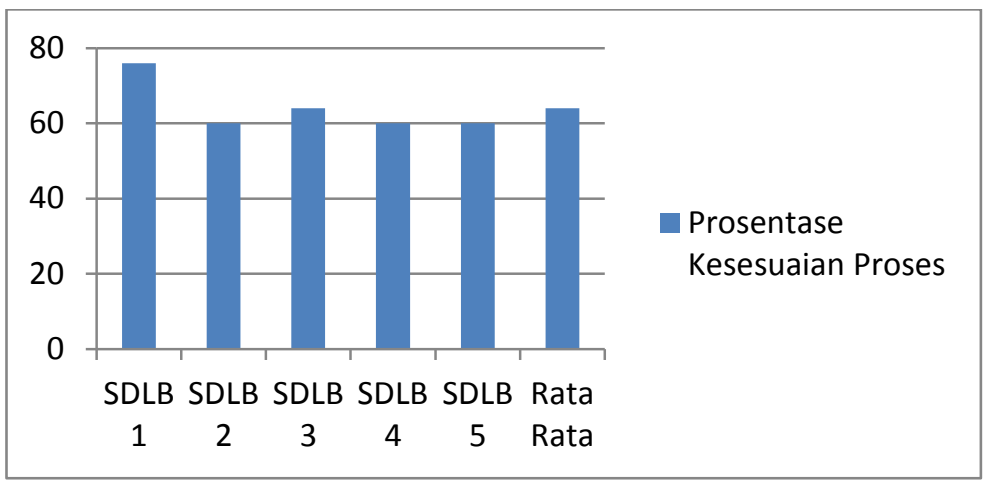

Grafik 1. Prosentase Tingkat Kesesuaian Proses Pengelolaan Sarana Prasarana Sekolah

Dari grafik diatas dapat disimpulkan bahwa SDLB Kedung Kandang melaksanakan prosedur pelaksanaan proses pengelolaan sarana prasarana pendidikan jasmani sesuai dengan modul pengelolaan sarana prasarana sekolah Kemendikbud, dengan nilai prosentase kesesuaian $76 \%$. Kemudian SDLB Sumber Darma memiliki nilai kesesuaian proses $60 \%$, SDLB BCG Idayu 64\%, SDLB Putra Jaya 60\% dan SDLB River Kids $64 \%$. Rata rata kesesuaian proses pelaksanaan pengelolaan sarana prasarana pendidikan jasmani SDLB Kota Malang sebesar $64 \%$ dalam kategori cukup baik.

Merujuk pada hasil wawancara dan studi dokumentasi pengelolaan sarana dan prasarana pendidikan jasmani di Sekolah Dasar Luar Biasa Kota Malang, ada beberapa tahap proses pelaksanaan pengelolaan yang mereka terapkan. Proses pelaksanaan pengelolaan yang mereka terapkan lebih merupakan kegiatan rutin serta tahapan prosesnya pun boleh dikatakan selalu sama dari tahun ke tahun. Jadi mereka (para pelaksana) sekedar hanya melakukan penyesuaian saja. Secara umum Sekolah Dasar Luar Biasa ini melakukan proses pelaksanaan pengelolaan sarana prasarana melalui tahapan proses antara lain: kegiatan perencanaan, kegiatan pengadaan, kegiatan penggunaan, pemeliharaan, inventarisasi, pengawasan (monitoring) serta pelaporan di SLB se-Kota Malang. Berikut ini adalah rangkuman proses pelaksanaan pengelolaan sarana prasarana SDLB Kota Malang:

\section{Kegiatan Perencanaan}

Pengelolaan sarana prasarana di SDLB diawali dengan kegiatan perencanaan. Semua SDLB se-Kota Malang melakukan kegiatan perencanaan 
pada setiap awal dimulainya tahun ajaran baru. Kegiatan perencanaan secara menyeluruh tertuang dalam RKS (Rencana Kerja Sekolah). Untuk sarpras Pendidikan Jasmani, Guru Penjaskes melakukan observasi yang berkaitan dengan apa saja yang dibutuhkan peserta didik berkaitan dengan sarana prasarana pendidikan jasmani. Setelah hasil observasi yang berupa daftar kebutuhan tersusun, guru kemudian menyerahkannya kepada kepala sekolah. Kepala Sekolah dibantu olah Admin/Sekertaris mengevaluasi kembali daftar kebutuhan tersebut untuk disesuaikan dengan besaran anggaran dana serta skala prioritas sebelum memasukannya dalam Rencana Anggaran Belanja (RAB). Analisis kebutuhan sarana dan prasarana adalah kegiatan menetapkan dan memikirkan program pengadaan fasilitas sekolah baik yang berbentuk sarana maupun prasarana yang akan dilakukan di masa mendatang untuk mencapai tujuan tertentu (Munir, 2014).

2. Kegiatan Pengadaan

Kepala Sekolah bersama dengan Koordinator Yayasan melakukan kegiatan pengadaan sarana dan prasarana di SDLB dengan mengacu pada kegiatan perencanaan yang telah dilakukan sebelumnya. Anggaran dana pengadaan bersumber dari orang tua wali murid, pemerintah dan pengajuan proposal ke yayasan. Kriteria mengenai pengadaan aset sarpras ditetapkan oleh Kepala Sekolah dengan berkoordinasi dengan Koordinator Yayasan. Tidak seluruh aset sarpras diadakan dengan cara membeli, akan tetapi ada pula aset sarpras yang diadakan dengan cara memodifikasi dan memperbaiki saja. Tidak ada pembentukan panitia pengadaan secara resmi di SDLB, para pelaksana adalah pelaksana yang sama seperti tahun tahun sebelumnya. Hal mengenai suratmenyurat dan kebutuhan administratif lelang pengadaan, para pelaksana hanya melakukan penyesuaian dari surat-surat dan dokument tahun lalu.

3. Inventarisasi

Inventarisasi adalah kegiatan untuk melakukan pendataan, pencatatan dan pelaporan hasil pendataan barang (Nastiti \& Kusumawati, 2014). Inventarisasi atau pencatatan aset sarpras di SDLB Kota Malang dilakukan oleh petugas yang telah ditunjuk. Kegiatan inventarisasi ini dilakukan sebagai data base dan kearsipan sehingga aset-aset yang dimiliki sekolah dapat diketahui dengan mudah. Biasanya pelaksanaan kegiatan pencatatan/inventarisasi atas aset sarpras ini 
dilakukan sebelum didistribusikan ke kelas-kelas. Tentu saja hal ini dilaksanakan setelah prosen pengadaan selesai. Pencatatan tersebut dituangkan dalam Buku Induk Inventaris Barang.

4. Penggunaan, Penyimpanan, Pemeliharaan dan Perbaikan

Seluruh warga sekolah memiliki hak akses yang sama dalam penggunaan aset sarpras yang ada dan dimiliki SLB di Kota Malang. Tentu saja melalui penjadwalan dan pencatatan arus keluar masuk barang yang ketat. Penggunaan aset sarpras di SLB harus memprioritaskan penggunaan yang sifatnya menunjang dalam proses belajar mengajar oleh guru dan anak didik. Sebagian besar sekolah belum mempunyai ruangan/gudang sebagai tempat penyimpanan sarana pendidikan jasmani. SLB se-Kota Malang rata-rata menyimpan alat-alat olahraga ditempat seadanya dan tidak ada ruangan khusus sebagai tempat penyimpanan alat olahraga tersebut. Untuk penyimpanan sarana olahraga setiap sekolah berbedabeda. Ada penyimpanan alat olahraga di lemari, ada yang dibawah tangga, memanfaatkan celah dibawah tangga untuk menyimpan alat olahraga.

Pemeliharaan sarana dan prasarana pendidikan adalah kegiatan untuk melaksanakan pengurusan dan pengaturan sarana dan prasarana agar selalu dalam keadaan baik dan siap untuk digunakan dalam mencapai tujuan pendidikan (Suliyarti, 2019). Pemeliharaan dan perbaikan (maintenance and repair) dilakukan melalui kebijakan dan peraturan mengenai pemeliharaan dikeluarkan sekolah, untuk menjamin keterpeliharaan aset sarpras yang ada. Anggaran yang dialokasikan khusus untuk pemeliharaan dan perbaikan dikeluarkan sekolah setiap tahunnya. Sedangkan berkenaan dengan jumlah alokasi dana perawatan dan perbaikan akan disesuaikan dengan pelaporan tahunan kondisi sarana prasarana sekolah. Beberapa sarana dan prasarana membutuhkan jadwal perawatan rutin untuk menjaga kondisi sarana tersebut.

\section{Pengawasan (Monitoring)}

Pengawasan adalah kegiatan mengukur tingkatan efektivitas kerja personal dan efisiensi penggunaan metode dan alat tertentu dalam usaha mencapai tujuan. Untuk itu diperlukan pengamatan langsung maupun tidak langsung terhadap berbagai aspek atau kegiatan dalam proses pencapaian tujuan (Nurbaiti, 2015). Pengawasan (monitoring) sarana dan prasarana pembelajaran di SLB se-Kota 
Malang dilakukan oleh Kepala Sekolah beserta staff admin yang ditunjuk. Kepala Sekolah berkoordinasi dengan yayasan dalam kegiatan monitoring ini. Monitoring dilakukan secara rutin oleh koordinator yang ditunjuk yayasan. Kepala Sekola akan melakukan pendampingan saat kegiatan monitoring dilakukan dengan tujuan dapat memberikan masukan dan saran.

6. Penghapusan

Mengenai kegiatan penghapusan ini SDLB di Kota Malang belum memiliki aturan yang baku. Tidak ada rekaman hasil atas kegiatan penghapusan dalam pengelolaan sarpras di sekolah. Peneliti mengalami kesulitan untuk menemukan diokomen mengenai kegiatas penghapusan aset dalam pengelolaan sarpras di SLB Kota Malang.

7. Pelaporan

Hasil rekaman / pencatatan kegiatan monitoring kemudian dilaporkan ke yayasan setiap 3 bulan. Untuk aset sarpras yang pendanaannya diberikan oleh pemerintah. Pelaporan pun dilakukan sekolah kepada pemerintah sebagai pertanggung jawaban atas penggunaan dana yang dipergunakan untuk sarpras tersebut. Selain hal tersebut diatas, sekolah pun memberikan laporan kepada orang tua peserta didik setiap waktu yang telah ditentukan secara rutin.

\section{SIMPULAN}

Dari uraian data dan hasil pembahasan diatas, maka dapat diambil kesimpulan bahwa:

1. Proses pelaksanaan pengelolaan sarana dan prasarana pendidikan jasmani di SDLB se-Kota Malang memiliki prosentase kesesuaian dengan modul proses pengelolaan sarana prasarana yang diterbitkan Kemendikbud dengan nilai kesesuaian proses sebesar $64 \%$ termasuk dalam kategori cukup baik.

2. Kegiatan perencanaan dilakukan dengan cara melakukan analisa kebutuhan terlebih dahulu. Penetapan kebutuhan dipenuhi dengan skala prioritas dan disesuaikan dengan anggaran. Seluruh perencanaan termuat di dalam RKS dan RAB.

3. Pengadaan sarana dan prasarana di SDLB Kota Malang tidak membentuk tim pengadaan secara formal dan eksplisit, akan tetapi proses pengadaan tetap 
melibatkan warga sekolah yang ditunjuk dan kompeten dalam hal pengadaan.

4. Inventarisasi dilakukan pencatatan berkaitan dengan aset sarana dan prasarana dalam Buku Induk Inventarisasi Barang.

5. Penyimpanan dilakukan di ruang seadanya. Penggunaan dilakukan dengan membuat aturan dan pencatatan yang ketat. Pemeliharaan dan Perbaikan dilakukan oleh warga sekolah sendiri dan tenaga ahli.

6. Monitoring dilakukan dengan koordinasi Kepala Sekolah dan yayasan.

7. Seluruh hasil pencatatan selama proses pengelolaan dilaporkan dalam betuk buku laporan triwulan dan tahunan.

8. Belum ada proses penghapusan yang valid di SDLB Kota Malang. Belum ada dokumen atau arsip yang ditemukan yang berkaitan dengan proses penghapusan dalam pengelolaan sarpras di SDLB Kota Malang.

\section{DAFTAR RUJUKAN}

Bancin, A., \& Lubis, W. (2017). Manajemen Sarana Dan Prasarana Pendidikan (Studi Kasus Sma Negeri 2 Lupuk Pakam). Educandum: Jurnal Manajemen Pendidikan PPs Unimed, 10(1).

Darmastuti, H. (2014). Manajemen Sarana Dan Prasarana Dalam Upaya Peningkatan Kualitas Pembelajaran Pada Jurusan Teknik Komputer Dan Informatika di SMK Negeri 2 Surabaya. Jurnal Inspirasi Jurnal Pendidikan, $3(3)$.

Hobri. (2010). Metodologi Penelitian Pengembangan Aplikasi pada Penelitian Pengembangan. Jember: Pena Salsabila.

Kemendikbud. (2019). Pengelolaan Sarana dan Prasarana Sekolah (MPPKS$S A R$. Direktorat Pembinaan Tenaga Kependidikan. Dirjen Guru Dan Tenaga Kependidikan: Kementerian Pendidikan dan Kebudayaan.

Kurniawati, P., \& Sayuti, S. (2013). Manajemen Sarana Dan Prasarana di SMK N 1 Kasihan Bantul. Jurnal Akuntabilitas Manajemen Pendidikan, 1(1), 98108. https://doi.org/https://doi.org/10.21831/amp.v1i1.2331

Megasari, R. (2014). Peningkatan Pengelolaan Sarana Dan Prasarana Pendidikan Untuk Peningkatan Kualitas Pembelajaran di SMPN 5 Bukit Tinggi. Jurnal Bahana Manajemen Pendidikan (JBMP), 2(1).

Miles, B. M., \& Huberman, M. (1992). Analisis Data Kualitatif Buku Sumber Tentang Metode-Metode Baru. Jakarta: UIP.

Munir, M. (2014). Manajemen Sarana Dan Prasarana Dalam Upaya Peningkatan Mutu Pendidikan di SMA Negeri 12 Surabaya. Jurnal Inspirasi Manajemen 
Pendidikan, 4(4).

Nastiti, F. E., \& Kusumawati, N. (2014). Sistem Informasi Inventarisasi Sarana Dan Prasarana Sekolah (Studi Kasus: Madrasah Tsanawiyah Muhammadiyah Surakarta). Jurnal Sistem Komputer, 4(2).

Nurbaiti. (2015). Manajemen Sarana Dan Prasarana Sekolah. Jurnal Manajer Pendidikan (MAPEN), 9(5).

Rahayu, S. (2019). Manajemen Sarana Dan Prasarana Pendidikan. https://doi.org/https://doi.org/10.31227/osf.io/76wb8

Satori, D., \& Irawan, A. (2013). Pengaruh Regulasi, Pembiayaan Dan Partisipasi Masyarakat Terhadap Efektivitas Manajemen Sarana Prasarana Sekolah, Dan Dampaknya Terhadap Efektivitas Pembelajaran Pada Sekolah Menengah Pertama Se Kota Sukabumi. Jurnal Administrasi Pendidikan, 17(1).

Suliyarti, R. (2019). Manajemen Pemeliharaan Sarana Dan Prasarana Pendidikan Untuk Meningkatkan Kualitas Pendidikan. https://doi.org/https://doi.org/10.31227/osf.io/qj3x4 